\title{
Chapter 28 \\ Governance for Realizing Multifunctional Floodplain: Flood Control, Agriculture, and Biodiversity in Yolo Bypass Wildlife Area, California, USA
}

\author{
Mahito Kamada, Jun Nishihiro, and Futoshi Nakamura
}

\begin{abstract}
Yolo Bypass (YB) is an engineered floodplain bypass for flood control in Sacrament River Valley in California, USA. Although the main purpose of the YB is to prevent the capital city of Sacramento and nearby riverside communities, the bypass provides wildlife habitats for various organisms and a good farming ground for multiple seasonal crops. Thus, we can refer to this facility as green infrastructure. We conducted an interview with key persons involving in the establishment and management of Yolo Bypass Wildlife Area (YBWA) in 2015 and reviewed the history of collaboration of various sectors with literature mining. Finally, we clarified the schematic relationship of stakeholders in the establishment and management of YBWA in which federal, state, and local entities and individuals take years of meetings, discussions, negotiation, and trust-building to reach consensus for restoration and management of the wildlife area.
\end{abstract}

Keywords Governance · Nature-based solution · Green infrastructure ·

Restoration · Wetland

\footnotetext{
M. Kamada $(\bowtie)$

Research Center for Management of Disaster and Environment, Tokushima University, Tokushima, Japan

Department of Civil and Environmental Engineering, Graduate School of Technology, Industrial and Social Sciences, Tokushima, Japan

e-mail:kamada@ce.tokushima-u.ac.jp

J. Nishihiro

Center for Climate Change Adaptation, National Institute for Environmental Studies, Tsukukba, Japan

F. Nakamura

Laboratory of Ecosystem Management, Graduate School of Agriculture, Hokkaido University, Sapporo, Japan
}

F. Nakamura (ed.), Green Infrastructure and Climate Change Adaptation, Ecological Research Monographs, https://doi.org/10.1007/978-981-16-6791-6_28 


\subsection{Introduction}

Nature-based solutions $(\mathrm{NbS})$ in flood risk reduction, which are "actions (1) inspired by, (2) supported by or (3) copied from nature (European Commission 2015)," has been required as an adaptation to climate change (Jongman 2018; Hartmann et al. 2019). The NbS bring multiple benefits to people and social systems, such as ecological issues, agriculture, and tourism (Hartmann et al. 2019), and incorporating green infrastructure is an effective way to reduce disaster risk in a changing climate. While for realizing the $\mathrm{NbS}$ as well as installation and management of the green infrastructure, involvement with more diverse stakeholders, including different administrations, businesses, NGOs, landowners, and citizens, is required than in the traditional engineering approach, and governance strategies are necessitated (Driessen et al. 2018).

Yolo Bypass (YB) is an engineered floodplain setting in Sacrament River Valley in California, USA, for flood control (Figs. 28.1 and 28.2). Several studies clarified that YB has an important role not only for flood control but also for agricultural use and biodiversity (Sommer et al. 2001; Garnche and Howitt 2011; Greco and Larsen 2014; Suddeth and Lund 2016). In addition, Wildlife Area has been established in the YB through the involvement with many stakeholders under the facilitation of a nonprofit organization (NPO), Yolo Basin Foundation (YBF) (Brice 2015). Yolo Bypass Wildlife Area (YBWA) provides excellent examples for designing multifunctional floodplain (Garnche and Howitt 2011; Greco and Larsen 2014) and for governance structure for realizing NbS (Salciso 2012; Brice 2015).

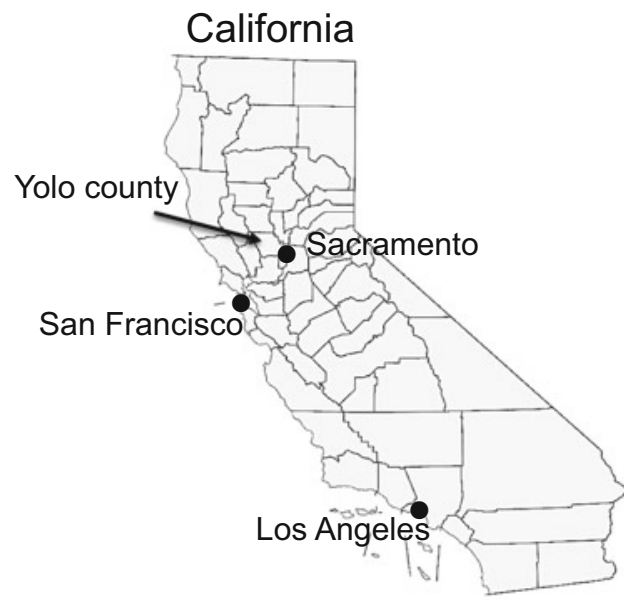

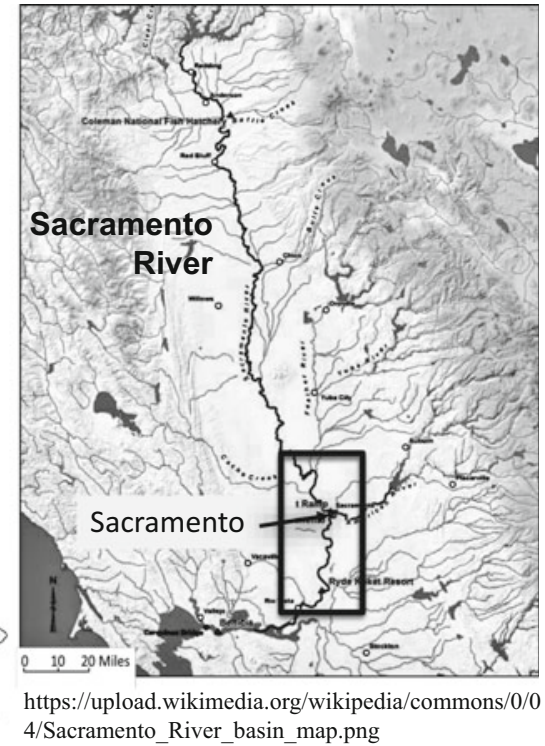

Fig. 28.1 Map of Sacrament River Valley. Square area is shown in Fig. 28.2 


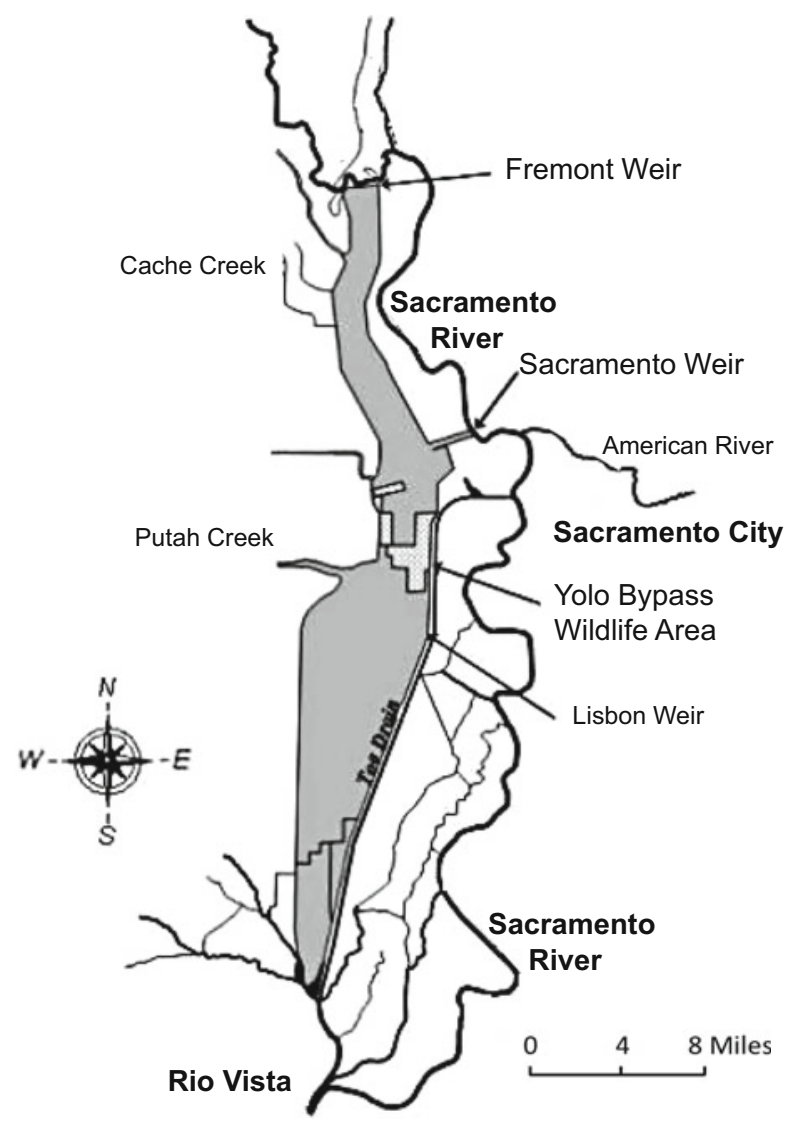

Fig. 28.2 Location of Yolo Bypass and Yolo Bypass Wildlife Area

In this report, we review a process of establishment and management of YBWA based on an interview with key persons as well as literature mining.

\subsection{Interview and Inspection}

The interview was conducted on December 1, 2015, at the headquarter and field in the YBWA. Ms. Robin Kulakow, Mr. Jack DeWit, and Mr. Jeff Stoddard explained to us the history, structure, and management system of the YBWA (Fig. 28.3). Kulakow was a Founder and Executive Director of the YBF, and DeWit was a Director of the YBF and a farmer who kept rice fields in the YBWA. Stoddard was a manager of the YBWA, worked at the California Department of Fish and Wildlife (CDFW). 


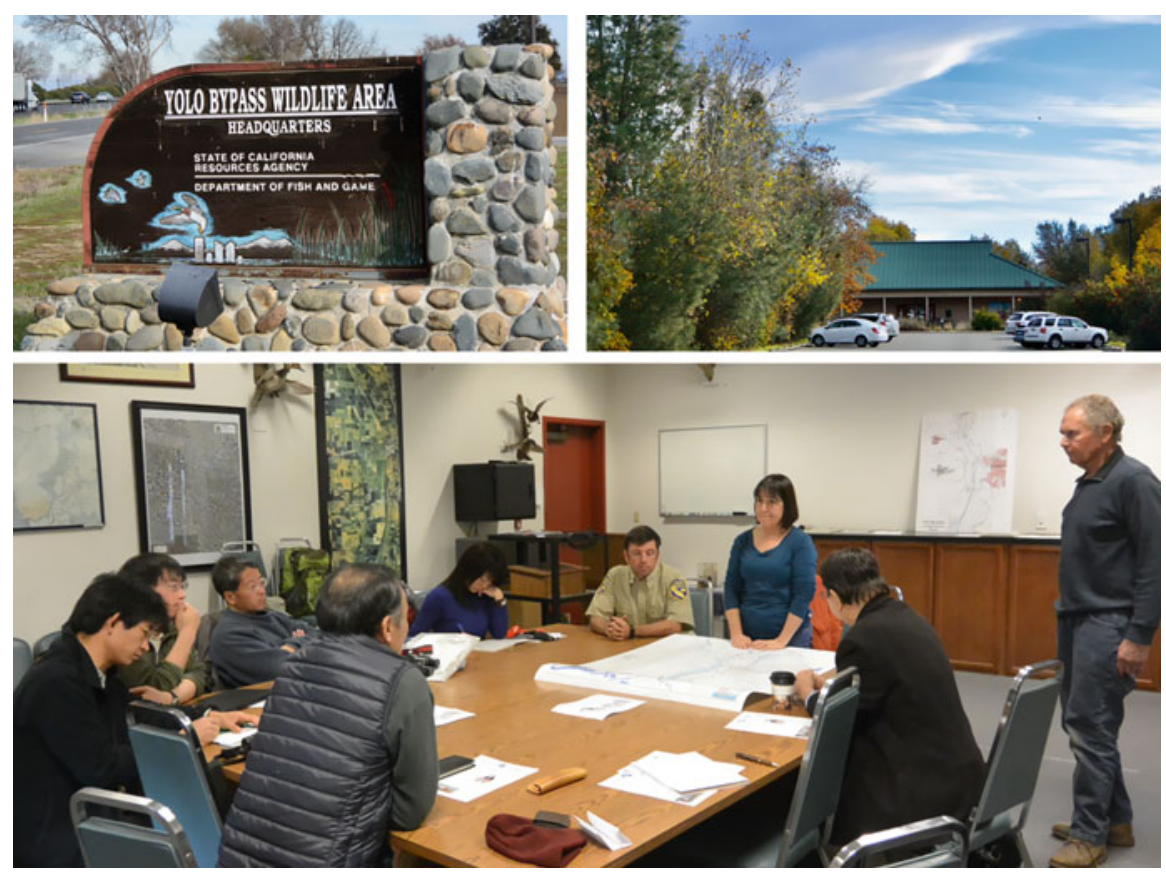

Fig. 28.3 Interview with the key persons was conducted at the headquarter and field in the YBWA on December 1, 2015

\subsection{Background of Yolo Bypass}

The Sacrament River flows the south in the Sacrament Valley and connects with Feather and American Rivers just above Sacrament City (Figs. 28.1 and 28.2). Before reclamation, the Sacramento River flooded almost yearly in response to winter rains and spring snowmelt (Suddeth and Lund 2016). The Yolo Basin along the Sacramento River, filled with water from three rivers for most of the winter months; the basin could be inundated for more than 100 days (Christian-Smith 2010). Flooding provided seasonal marshy habitat for tule elk, fishes, and waterfowl; as the valley was located along the Pacific Flyway, millions of waterfowl migrated for wintering in the early nineteenth century (Brice 2015).

From the middle of the nineteenth century, after California Gold Rush, reclamation for agriculture began (Brice 2015), and now only 6\% of the historical wetlands and $11-13 \%$ of the riparian vegetation remain (Katibah 1984; Suddeth and Lund 2016). In accordance with land development, social demand for flood control was increased. In 1911, the Flood Control Act was established by the state and construction of two bypasses, the Yolo and Sutter, were started. In 1917, the Sacramento River Control Project as a federal flood control act was established (Brice 2015). 
Based on the concept to construct a broad system mimicking the Sacrament River's natural floodplain function, which was originally proposed by Will Green in 1860s, the US Army Corps of Engineers (Corps) developed a network of weirs and bypasses to protect Sacramento City and other communities. The bypass systems were completed by 1930, and a series of dams were completed around 1943 (Sommer et al. 2001; Greco and Larsen 2014).

The YB is 24,000 ha leveed floodplain, $64 \mathrm{~km}$ long and $2-4 \mathrm{~km}$ wide. The maximum design flow for the Sacrament River channel below the Sacrament metropolitan area is $3100 \mathrm{~m}^{3} / \mathrm{sec}$, and the YB is engineered to convey $14,200 \mathrm{~m}^{3} / \mathrm{sec}$ for 100-year protection (Sommer et al. 2001; Christian-Smith 2010; Greco and Larsen 2014; Brice 2015). The main flood flows into the bypass from Fremont Weir (Fig. 28.2) when the water level of Sacramento River exceeds $10 \mathrm{~m}$ (Suddeth and Lund 2016). The flood frequency is approximately 1.6 years, varying in duration from 3 to 83 days in the period of 1980-2010 (Greco and Larsen 2014).

According to Garnche and Howitt (2011) and Salciso (2012), about 75\% of the YB is privately owned, except for the YBWA. Two-thirds of the floodplain are used for farming and grazing in the spring and summer, while the rest is mostly wetlands. Farmers have water rights and are subject to flood easement. The State Reclamation Board has the right to inundate the land with floodwaters. They prevent landowners from building structures and berms and need not provide compensation for losses due to flooding.

\subsection{Yolo Bypass Wildlife Area and its Management}

The creation of the YBWA has resulted in restoration and management of wetland, riparian, and grassland communities that provide habitat for a diverse assortment of plant, wildlife, and fish species and the creation of educational and interpretive programs and partnerships to serve the public. The notable traditions of agriculture have also been maintained throughout the YBWA, employing innovative wildlifefriendly management strategies to achieve multiple resource objectives (CDFG 2008).

In 1991, California Wildlife Conservation Board (WCB) purchased the land of 1275 ha in YB for $\$ 4.75$ million and 237 ha in 1994 (WCB 2001). The US House of Representatives approved \$1.6 million for the Yolo Basin Wetland Project implemented by the Corps as the federal sponsor (Brice 2015). The NPO Ducks Unlimited cooperated on the project in designing ponds and contracting bulldozers, backhoes, and tree-planters in the project (Hayes 1999). The first stage of wetland restoration was completed, and the Corps turned over the 1512 ha YBWA to the California Department of Fish and Game (CDFG, forerunner of CDFW) to manage on November 12, 1997 (Hayes 1999; Brice 2015).

The YBWA was expanded to 6782 ha through land acquisitions by WCB in 2001 (5182 ha), 2002 (40 ha), and 2004 (48 ha) (WCB 2001, 2002, 2004). Ducks Unlimited and California Waterfowl Association each received \$4 million from the 
state and implemented restoration project (Brice 2015). According to Kulakow, Yolo County agreed with the wetland restoration only at the area unsuitable for farming. Finally, 3240 ha in the YBWA have been restored to seasonal and permanent wetland from fallow farmland (Christian-Smith 2010).

Stoddard said that CDFW has been responsible for managing 6776 ha habitat and 6 ha headquarters in YBWA. About a half of the habitat area has been leased for farming and grazing and managed by farmers, and the rest has been managed by the CDFW directly. According to YBF (2015), new five-year leases were negotiated in 2015 , and about 810 ha for wild and white rice and about 2400 ha for grazing cattle were agreed with two farmers, Jack DeWit and Tom Schene, respectively. Both lessees also agree to grow food plots for wildlife, such as milo, safflower, sunflower, Japanese millet, and water grass. Dixon Resource Conservation District has handled the lease and the funds generated by these leases (Brice 2015; YBF 2015). The leasing charge is set cheaper than the area outside YBWA to be an incentive for farmers, according to Stoddard, and it brings around $\$ 650,000$ a year and supports operations on the YBWA (YBF 2015).

Figure 28.4 shows one of the restored wetlands and facilities for pouring water. According to Kulakow and Stoddard, wetlands were designed by the Ducks Unlimited and the California Waterfowl Association. The land in YBWA is not

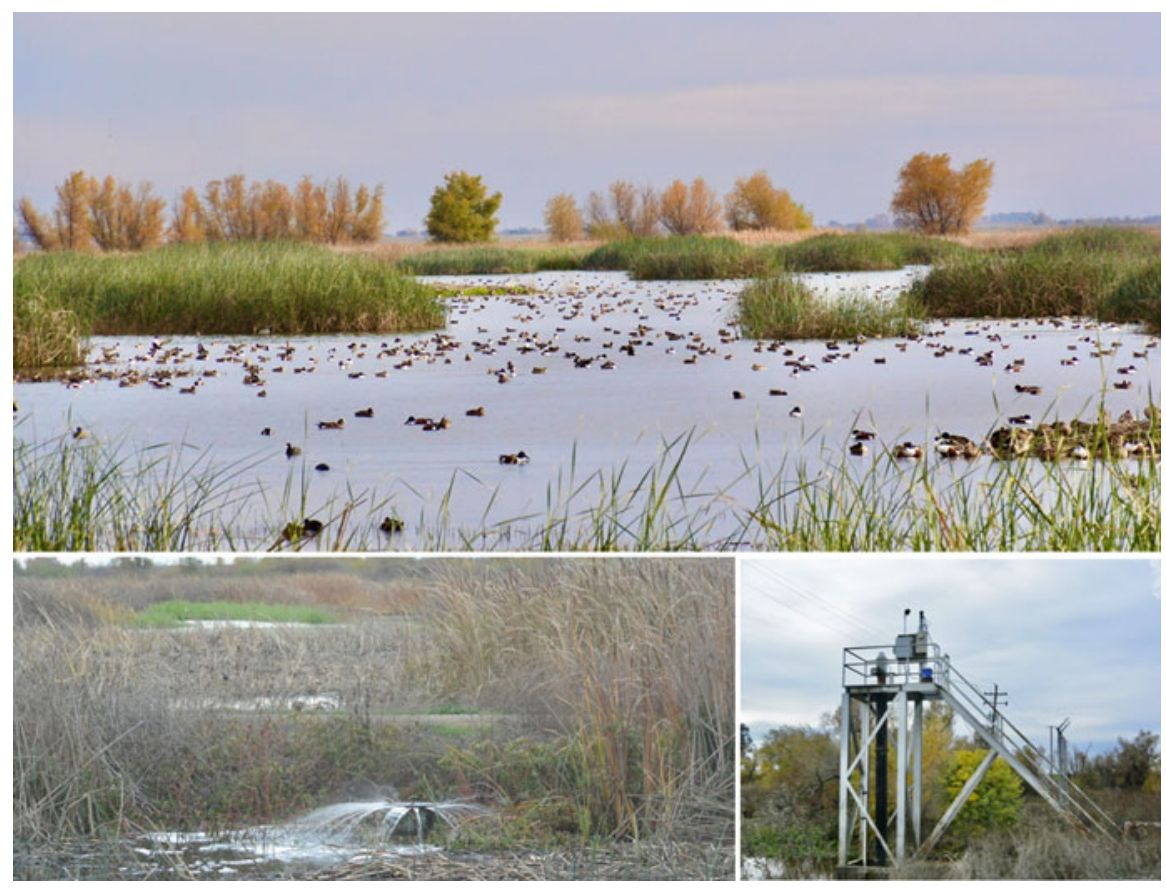

Fig. 28.4 Restored wetlands (upper photo) and facilities for pouring water (lower photos) (December 1, 2015) 


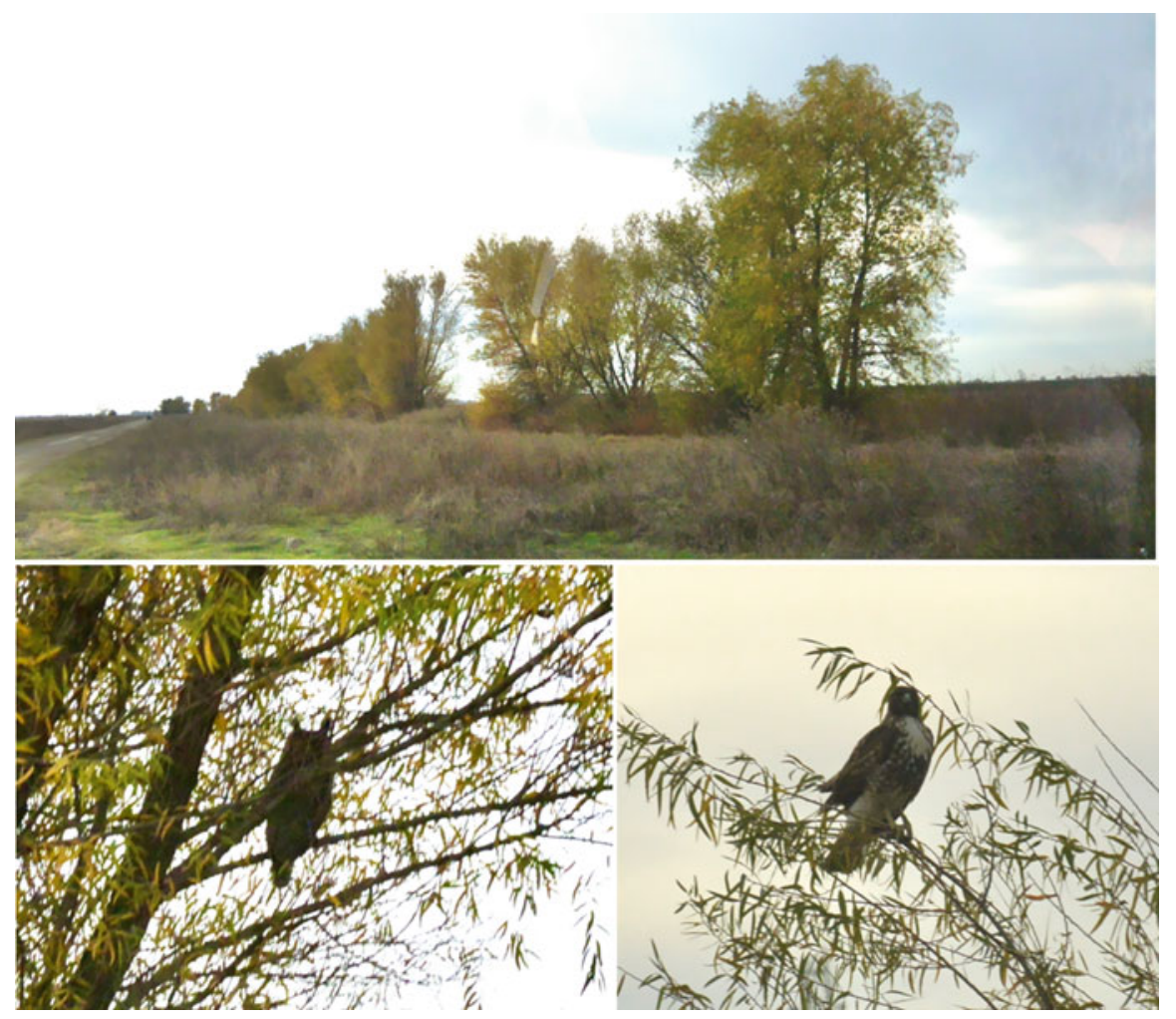

Fig. 28.5 A line of riparian willow trees has been remained and used as a resting site by raptors; great horned owl (L) and sharp-shinned hawk (R) (December 1, 2015)

always inundated, and therefore it is necessary to pump water into the area. The operation device is set at $7 \mathrm{~m}$ above the ground to prevent inundation during flooding.

Riparian woods have been seriously reduced and should be conserved and restored in Sacramento Valley. According to Kulakow, the federal office that is responsible for flood control allowed to maintain riparian trees along a direction of flooding flow, not to obstruct the flow. And thus, a line of willow trees has been remained and used as a resting site by raptors (Fig. 28.5).

Figure 28.6 shows a part of the area where DeWit has leased for rice farming. Rice cultivation is a practical way to create seasonal wetlands and stay vegetation in an early successional stage; rice is planted from April and harvested by October, and hence the field can be used for waterfowl in the winter season (CDFG 2008). Flooding rice fields after harvest helps decompose the rice straw, and the flooded fields provide an important food source with the rice that is left after harvest (YBF 2012). In addition, DeWit fallows about 94 ha of his 810 ha rice fields and then floods them around $10 \mathrm{~cm}$ deep for the shorebirds in the summer, usually 47 ha in 

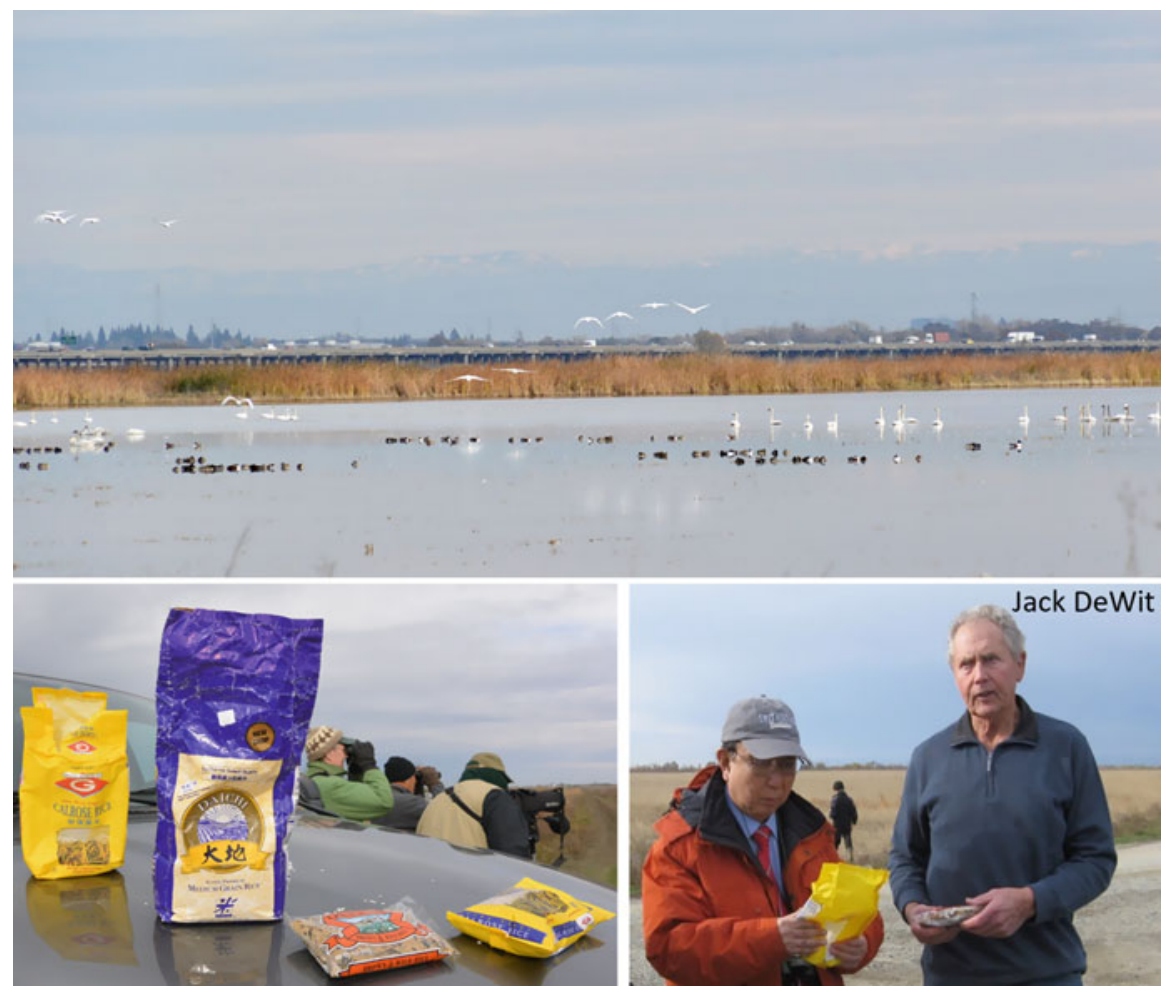

Fig. 28.6 Rice field, where Jack DeWit has rent and farmed, has been used as a wintering site for waterfowl (December 1, 2015)

July and 47 ha in August (Brice 2015). According to DeWit, he grows white rice and wild rice and exports white-waxy rice to Japan. The yield of wild rice is lower than the white rice, but the seeds become good feed for shorebirds and waterfowl. He can continue agricultural activities with additional efforts for birds because of the low leasing charge.

Under the land management plan (CDFG 2008), cattle grazing occurs on an extensive portion in the southern end of the YBWA (Fig. 28.7). According to Stoddard, cattle has been used as an alternative to elk, which has been already extinct in the area, for vegetation management through grazing. Cattles remove alien plants and keep vegetation height low, and it saves indigenous plant species adapting to the conditions with frequent flood disturbances and elk grazing before the reclamation of the floodplain. The moderate density of cattle grazing also contributes to the maintenance of wet grasslands called vernal pools, which provide habitat for rare animals such as the Mexican tiger salamander.

In the grassland area, "Umbrella Barn" has been kept as a historical resource; it was built around 1913 for providing refuge for the livestock during high water (CDFG 2008). Raccoon and short-eared owl were using when we visited (Fig. 28.8). 

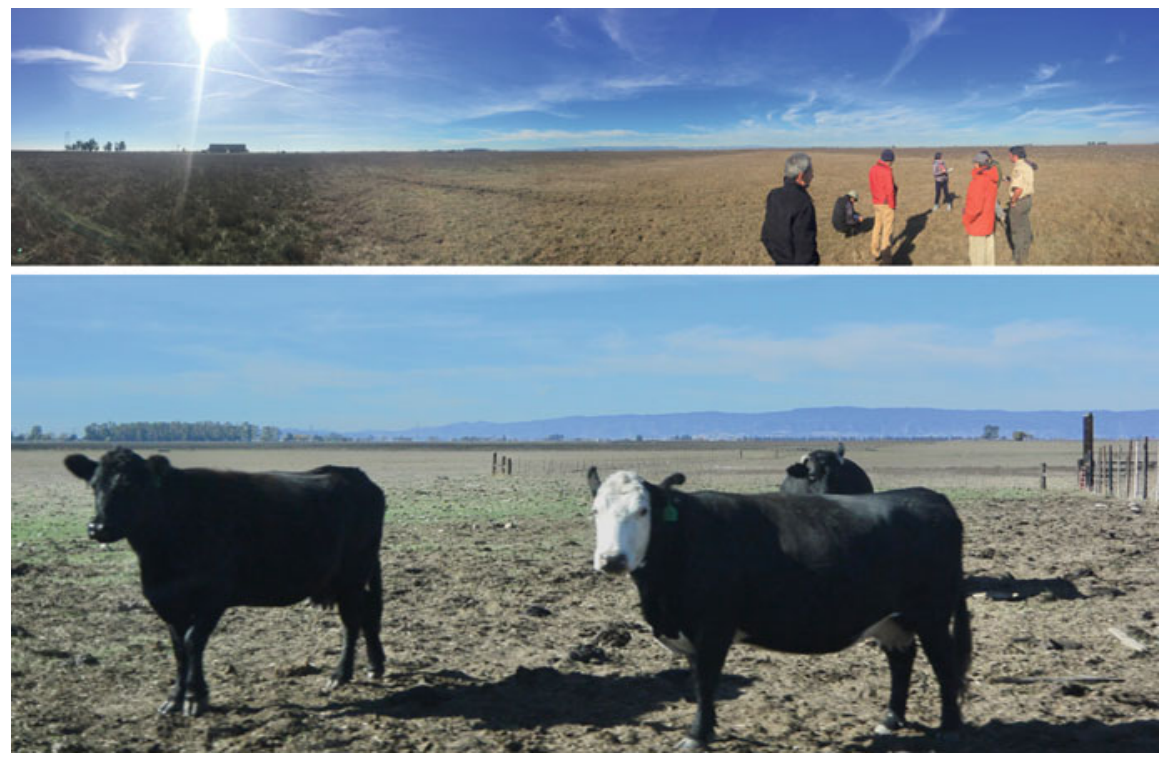

Fig. 28.7 Grassland area managed by cattle grazing (December 1, 2015)

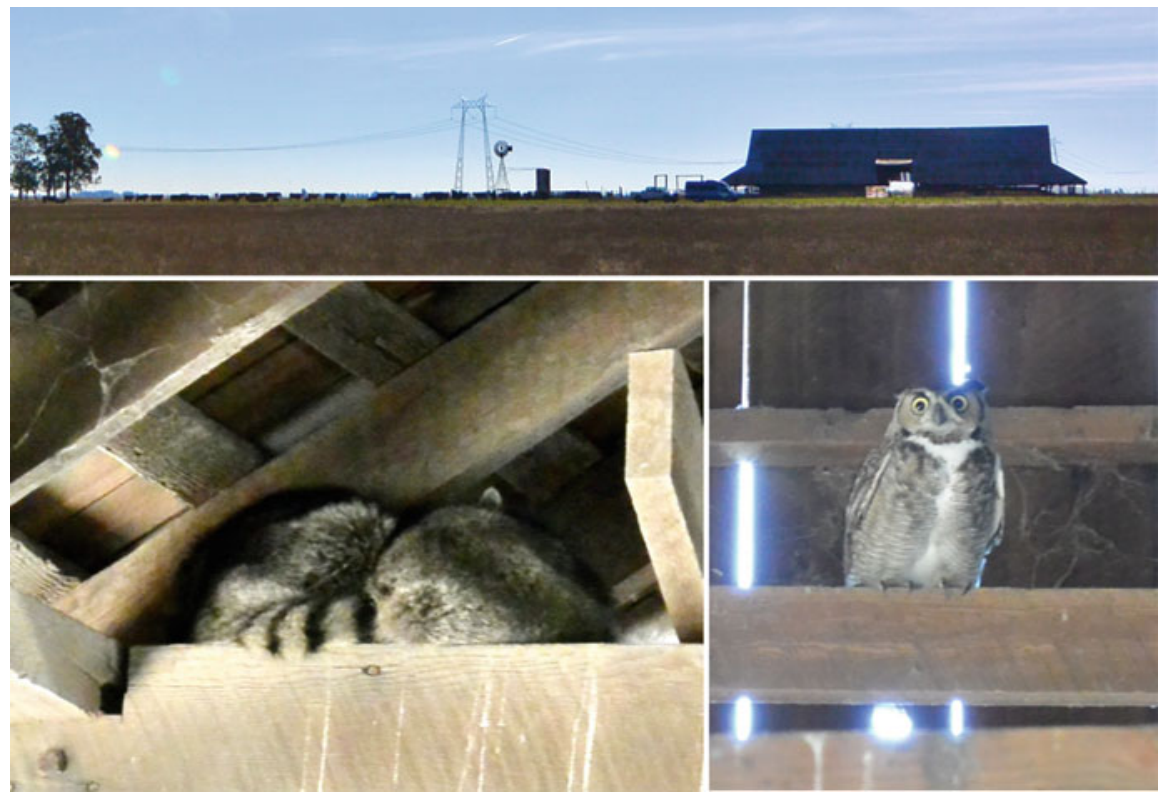

Fig. 28.8 "Umbrella Barn" has been remained in the grassland area as a historical monument. It was occupied by raccoon (L) and short-eared owl (R) (December 1, 2015) 
Duck hunting is another significant use of the YBWA. The rise of duck clubs was in the first half of the twentieth century, and it was the beginning of waterfowl protection (Brice 2015). Various duck hunting clubs operate in the YBWA. During the season, waterfowl, coots, moorhens, snipe, pheasant, and doves are hunted (Brice 2015). Hunting license (\$160/year) and hunting (\$26/day) fees are important sources of income to help with the management. A variety of other activities, such as fishing, wildlife viewing, and environmental education, occur throughout the year (CDFG 2008).

\subsection{Significant Role of Yolo Basin Foundation in Governance Structure}

Figure 28.9 summarizes the schematic relationship of stakeholders in the establishment and management of YBWA. According to the CDFG (2008), "planning for the YBWA encompasses issues that cross regional, local, and project area boundaries. This section identified the federal, state, county, and local agencies and other planning influences that effect the function and management planning of the YBWA." YBF took a significant role in the process. The YBF is an NPO created in 1990 as a community-based organization to facilitate the creation of the YBWA (Salciso 2012).

Brice (2015) described the starting point of the actions forward the YBWA as follows: Ted Beedy and his fellow birders knew that the YB area was a significant place for birds when flooded, and "a year-round managed wetland" became the dream. They drew a conceptual map and later developed a plan for a refuge. Beedy took US Congressman Vic Fazio to the proposed site, and the plan was favored by him. The plan gained momentum with support from the Yolo County Board Supervisors, the US Fish and Wildlife Service, and California Waterfowl Association. Then, it brought the decision-making of WCB to purchase the land in the YB for the wildlife area in 1991.

Kulalow, a founder of the YBF, joined the core group with the idea of forming an NPO to support the proposal. That group was to become the YBF. In the interview, Kulakow said, "the idea was born in the kitchen, when I was talking and drinking tea with friends,, and wrote, "in 1989 Susan and I had filed the incorporation papers for Putah Creek Council. One year later we were it again for a new nonprofit named Yolo Basin Foundation. We wrote newsletter articles, membership appeals, thank you letters, and press releases while our sons played on the floor (YBF 2016)."

YBF recognized from the beginning that there is a complex web of policies and other influences that need to be reconciled (CDFG 2008). The ground-level work to make consensus among federal, state, and local entities and individuals took years of meetings, discussions, negotiation, and trust-building (Salciso 2012). The YBF, as an NPO outside of the formal structure of the legal management of the area, had an important role in analyzing and coordinating exiting legal obligations and policy objectives with restoration plans (Salciso 2012). 


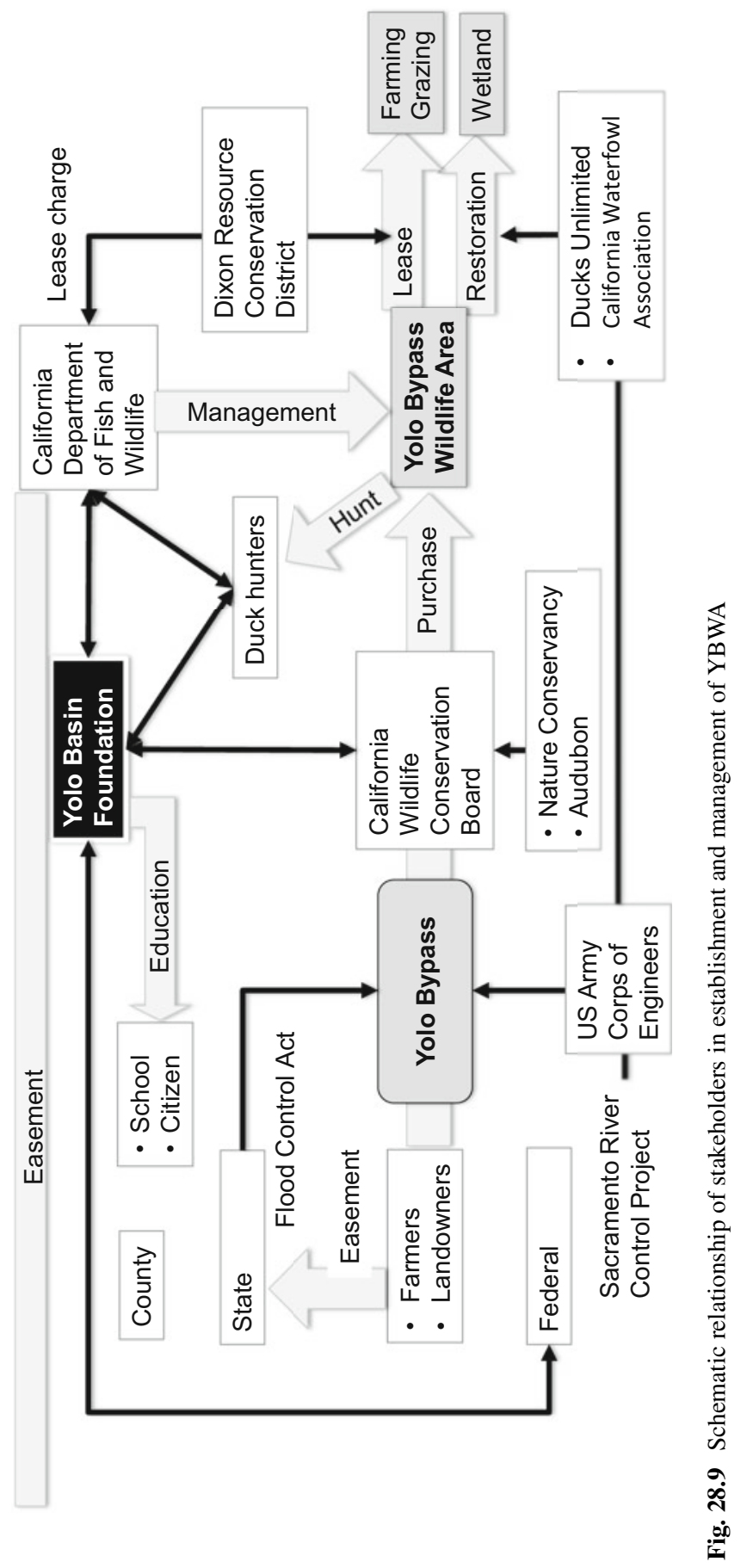


In 1998, the YBF initiated the Yolo Bypass Working Group (YBWG) under a CALFED Ecosystem Restoration Program Grant (CDFG 2008). The YBWG meetings were served as a forum to educate and inform all parties interested in the Yolo Bypass, approximately every 2-4 months. Information on bypass-related land use, flood management, resource policy, proposed projects, economics, and ecological issues is presented and openly discussed by members (CDFG 2008). More than 30 people representing a wide range of stakeholders regularly attended these meetings (Table 28.1).

Before the YBWG was formed, many landowners and other stakeholders were not informed about issues and decision-making processes. These meetings gave local stakeholders the chance to provide direct input, helping to protect their interests and guide projects proposed by others (CDFG 2008). After frequent meetings, the YBWG produced "A Framework for the Future: Yolo Bypass Management Strategy." Two general land use categories, agriculture with integrated enhancement and habitat enhancement as the primary land use, were recommended in the framework. The YBWG said that the YBWA could be a place where realistic goals and objectives could be achieved, resulting in benefits for all parties involved (YBF 2001; Salciso 2012). The YBWG meetings were continuously held, a total of 37 meetings until 2006, and then finally "Yolo Bypass Wildlife Area Land Management Plan (LMP)" was publicized in 2008 as the fundamental guideline (CDFG 2008).

Table 28.1 Participants in Yolo Bypass Working Group, after CDFG (2008)

\begin{tabular}{l}
\hline - Landowners and their tenants (farmers, ranchers, duck hunters) \\
\hline - California Department of Fish and Game \\
\hline - California Department of Water Resources \\
\hline - State Reclamation Board \\
\hline US Fish and Wildlife Service \\
\hline - Natifornia Department of Food and Agriculture \\
\hline - Sacramento-Yolo Mosquito and Vector Control District \\
\hline - Dixon and Yolo Resource Conservation Districts \\
\hline - Sacramento Area Flood Control Agency \\
\hline - Yolo County \\
\hline - Cities of West Sacramento \\
\hline - Woodland and Davis \\
\hline California Waterfowl Association \\
\hline Ducks Unlimited \\
\hline National Oceanic and Atmospheric Administration \\
\hline National Marine Fisheries Service \\
\hline - Port of Sacramento
\end{tabular}




\subsection{Environmental Education by Yolo Basin Foundation}

YBF's activities on managing YBWG are based on its mission, "expanding public appreciation and stewardship of wetland in the Yolo Basin through education and innovative partnerships (https://www.yolobasin.org/about/)." Another and rather their main activity is the facilitation of environmental education in the YBWA, carried out by a 20-member board of directors, a small staff, and over 100 volunteers (Brice 2015). Through the Discover the Flyway school program in the 2016-2017 school year, the YBF provided an educational program to 3656 students and 172 teachers of 181 classes from 58 schools (YBF 2017). The YBF is also the sponsoring NPO for California Duck Days, publishes the Yolo Flyway Newsletter, introduces the public to natural places in the community through public field trips, and hosts the popular Flyway Nights speaker series (CDFG 2008; Brice 2015).

Kulalow said in the interview that "because the area surrounding YBWA, such as West Sacrament, is now under urban development (Fig. 28.10), many people move into the area from outside. People living in the urban area, newcomers in particular, are surprised by explosive sound roaring which is happened to drive off birds from farmyards and loathe occurrence of mosquitoes from wetlands. Environmental education for the people is important to avoid or reduce the conflict."

Funding for YBF's programs is provided through individual and business memberships as well as by a wide variety of private-sector sponsors. Bucks for Ducks, a dinner and auction, is the YBF's fundraising event held every October since 1991 (CDFG 2008).

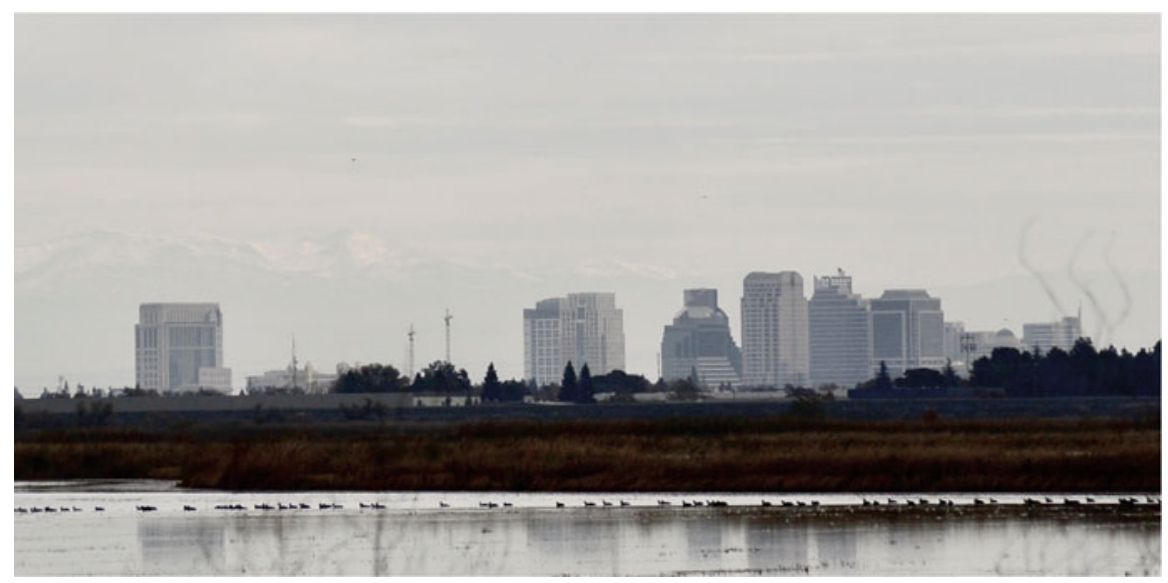

Fig. 28.10 Urban area developing at the area adjacent to wetlands for wildlife (December 1, 2015) 


\subsection{Concluding Remarks}

The YBWA has provided multiple functions for various people with different interests, and we can learn many things about the process of getting NbS. Groundlevel work to make consensus among federal, state, and local entities and individuals is essential, and a community-based organization takes a central role in forming a platform for meetings, discussions, negotiation, and trust-building. Kulalow, a founder and former Executive Director of the YBF, wrote that "no one worked with me because of the money. Everyone did it because we had shared values (YBF 2016)," and it must be a key for governance.

Another feature of the Yolo bypass is the funding mechanism. Most of the expenses required to manage YBWA are covered by paddy rental fees and hunter license fees. By incorporating these ecosystem services into the economic mechanism, management that balances flood control and biodiversity conservation has been achieved.

Acknowledgments We are grateful to Ms. Robin Kulakow, Mr. Jack DeWit, and Mr. Jeff Stoddard for their cooperation on the interview and to Mr. Kenji Seki, Mr. Ken-ichi Yoshiya, and Ms. Reiko Niwano of Ecosystem Conservation Society Japan for conducting and facilitating the survey on the Yolo Bypass Wildlife Area.

\section{References}

Brice A (2015) The yolo bypass wildlife area: history, management and significance for birds. CVBC Bulletin/Winter 2015. http://www.cvbirds.org/wp-content/uploads/2016/09/The-YoloBypass-Wildlife-Area-History-Management-and-Significance-for-Birds.pdf

CDFG (California Department of Fish and Game) (2008) Yolo Bypass Wildlife Area Land Management Plan. 370pp. https://nrm.dfg.ca.gov/FileHandler.ashx?DocumentID=84924\&inline

Christian-Smith J (2010) Managing for multiple benefits: farming, flood protection, and habitat restoration in the yolo bypass wildlife area. In: Christian-Smith $\mathbf{J}$ et al (eds) California farm water success stories. Pacific Institute, Oakland, pp 17-24. https://pacinst.org/wp-content/ uploads/2010/03/success_stories3.pdf

Driessen PPJ, Hegger DLT, Kundzewicz ZW, van Rijswick HFMW, Crabbé A, Larrue C, Matczak P, Pettersson M, Priest S, Suykens C, Raadgever GT, Wierug M (2018) Governance strategies for improving flood resilience in the face of climate change. Water 10(1):1595. https://doi.org/ $10.3390 /$ w 10111595

European Commission (2015) Towards an EU research and innovation policy agenda for NatureBased Solutions \& Re-Naturing Cities. In: Final report of the Horizon 2020 expert group on nature-based solutions and re-Naturing cities. European Commission, Brussels. https://doi.org/ $10.2777 / 765301$

Garnche C, Howitt RE (2011) Species conservation on a working landscape: the joint production of wildlife and crops in the Yolo Bypass floodplain. https://ageconsearch.umn.edu/record/103973/ files/AAEAv4.pdf

Greco S, Larsen EW (2014) Ecological design of multifunctional open channels for flood control and conservation planning. Landsc Urban Plan 131:14-26 
Hartmann T, Slavíkoá L, McCarthy S (2019) Nature-based solutions in flood risk management. In: Hartmann T, Slavíkoá L, McCarthy S (eds) Nature-based food risk management on private land - disciplinary perspectives on a multidisciplinary challenge. Springer Open, New York, pp $3-8$

Hayes PJ (1999) Yolo bypass wildlife area: birth of a wintering waterfowl wildland. Outdoor California, January-February 1999: 16-17

Jongman B (2018) Effective adaptation to rising flood risk. Nat Commun 9:1986. https://doi.org/ 10.1038/s41467-018-04396-1

Katibah EF (1984) A brief history of riparian forests in the Central Valley of California. In: Warner RE, Hnedrix KM (eds) California riparian ecosystems: ecology, conservation and productive management. University of California Press, Berkeley, pp 23-19

Salciso RE (2012) The success and continued challenges of the yolo bypass wildlife area: a grassroots restoration. Ecol Law Q 39(4):1085-1134

Sommer T, Harrell B, Nobriga M, Brown R, Moyle P, Kimmerer W, Schemel L (2001) California's yolo bypass - evidence that flood control can be compatible with fisheries, wetlands, wildlife, and agriculture. Fisheries 26(8):6-16

Suddeth GR, Lund JR (2016) Multi-purpose optimization for reconciliation ecology in an engineered floodplain: yolo bypass, California. San Francisco Estuary and Watershed Science 14(1):1-23. https://doi.org/10.15447/sfews.2016v14iss1art5

WCB (California Wildlife Conservation Board) (2001) State of California The Resource Agency Department of Fish and Games Wildlife Conservation Board Minutes August 30, 2001, 130pp

WCB (California Wildlife Conservation Board) (2002) State of California The Resource Agency Department of Fish and Games Wildlife Conservation Board Minutes May 23, 2002, 55pp

WCB (California Wildlife Conservation Board) (2004) State of California The Resource Agency Department of Fish and Games Wildlife Conservation Board Minutes February 19, 2004, 67pp

YBF (Yolo Basin Foundation) (2001) A Framework for the Future: Yolo Bypass Management Strategy. Jones \& Stokes (J\&S 99079), Sacramento, CA

YBF (Yolo Basin Foundation, Satter H) (2012) Jack DeWit, rice farmer at the Wildlife Area. Yolo Flyway 21(3):3. https://secureservercdn.net/72.167.242.48/h9k.1b4.myftpupload.com/ wp-content/uploads/PDF/yfnl/ybf_flyway_2012_fall.pdf

YBF (Yolo Basin Foundation) (2015) Farm and ranch leases at the Yolo Bypass Wild Area. Yolo Flyway 24(3):1-2. http://yolobasin.org/wp-content/uploads/2015/10/17077-YBF-Flyway-Fall2015.pdf

YBF (Yolo Basin Foundation) (2016) A letter from Robin .... Yolo Flyway 25(1):1-2. https:/ /secureservercdn.net/72.167.242.48/h9k.1b4.myftpupload.com/wp-content/uploads/2016/02/ 17428-YBF-Flyway-Winter-2016.pdf

YBF (Yolo Basin Foundation) (2017) Wildlife area news. Yolo Flyway 26(3):1-2. https:// www.yolobasin.org/wp-content/uploads/2017/10/YBF-Flyway-Fall-2017.pdf

Open Access This chapter is licensed under the terms of the Creative Commons Attribution 4.0 International License (http://creativecommons.org/licenses/by/4.0/), which permits use, sharing, adaptation, distribution and reproduction in any medium or format, as long as you give appropriate credit to the original author(s) and the source, provide a link to the Creative Commons license and indicate if changes were made.

The images or other third party material in this chapter are included in the chapter's Creative Commons license, unless indicated otherwise in a credit line to the material. If material is not included in the chapter's Creative Commons license and your intended use is not permitted by statutory regulation or exceeds the permitted use, you will need to obtain permission directly from the copyright holder. 